\title{
Why, where, and when do cardiac myocytes express inositol 1,4,5-trisphosphate receptors?
}

\author{
Martin D. Bootman and H. Llewelyn Roderick \\ Laboratory of Molecular Signalling, Babraham Institute, Babraham, Cambridge, United Kingdom
}

THE SEQUENCE OF EVENTS leading to a $\mathrm{Ca}^{2+}$ signal during cardiac excitation-contraction (EC) coupling is well known (3). With each beat, the propagating action potential depolarizes the sarcolemma of the excitable myocytes within the heart. Membrane depolarization leads to the activation of voltage-operated $\mathrm{Ca}^{2+}$ channels (VOCs), thereby causing a brief influx of $\mathrm{Ca}^{2+}$. The $\mathrm{Ca}^{2+}$ influx is sensed and amplified by $\mathrm{Ca}^{2+}$ release channels known as ryanodine receptors (RyRs), which are expressed on the sarcoplasmic reticulum (SR) in close apposition to the VOCs. The RyRs are activated by the $\mathrm{Ca}^{2+}$ permeating across the VOCs via a process known as $\mathrm{Ca}^{2+}$. induced $\mathrm{Ca}^{2+}$ release (CICR).

Although RyRs are the principal $\mathrm{Ca}^{2+}$ release channels within cardiomyocytes, they are not the only route for $\mathrm{Ca}^{2+}$ to be mobilized from intracellular stores. Cardiac myocytes also express inositol 1,4,5-trisphosphate $\left(\mathrm{InsP}_{3}\right)$ receptors $\left(\mathrm{InsP}_{3} \mathrm{Rs}\right)$, albeit at an $\sim 100$-fold lower level than RyRs. $\mathrm{InsP}_{3} \mathrm{Rs}$ are structurally and functionally similar to RyRs. They have the same tetrameric pinwheel structure and similarly possess carboxy-terminal transmembrane helices that form the ion pore and a large cytoplasmic amino-terminal portion. Although $\mathrm{InsP}_{3} \mathrm{Rs}$ absolutely require $\mathrm{InsP}_{3}$ for activation, they can also be considered as CICR channels, since cytosolic $\mathrm{Ca}^{2+}$ has a bimodal effect on $\mathrm{InsP}_{3} \mathrm{R}$ open probability similar to the action it has on RyRs (17).

Three $\mathrm{InsP}_{3} \mathrm{R}$ isoforms have been identified and cloned. They are expressed at distinctive ratios in different mammalian tissues. Studies have shown that the three $\operatorname{InsP}_{3} \mathrm{R}$ isoforms have subtly divergent properties (14). It is believed (although not yet widely demonstrated) that expression of different InsP $\mathrm{P}_{3} \mathrm{R}$ isoforms can generate distinct $\mathrm{Ca}^{2+}$ signals. Within the heart, it appears that adult atrial and ventricular myocytes express largely type $2 \operatorname{InsP}_{3} \mathrm{Rs}(9,10)$. The functional consequence of expressing this isoform in myocytes is unclear. Type $2 \mathrm{InsP}_{3} \mathrm{Rs}$ have the highest affinity for $\operatorname{InsP}_{3}$, but why this should relate to myocyte physiology is not known. Type 1 and type $3 \mathrm{InsP}_{3} \mathrm{R}$ isoforms may also be expressed in the heart, in particular within Purkinje cells (19) and neonatal myocytes (12).

Despite long-standing evidence for the expression of functional $\mathrm{InsP}_{3} \mathrm{Rs}$ in the heart (20), it is only recently that they have been convincingly shown to have a significant effect on the activity of cardiac myocytes. This is essentially due to a flurry of publications that have explored the involvement of InsP $\mathrm{P}_{3} \mathrm{Rs}$ in regulating cardiac EC coupling, development, pacemaking, and gene transcription. A study by Lothar Blatter and colleagues in the American Journal of Physiology-Heart and Circulatory Physiology (5a) provides yet more compelling

Address for reprint requests and other correspondence: M. D. Bootman, Laboratory of Molecular Signalling, Babraham Institute, Babraham, Cambridge CB22 3AT, UK (e-mail: martin.bootman@bbsrc.ac.uk). evidence for $\operatorname{InsP}_{3} \mathrm{Rs}$ being modulators of cardiomyocyte signaling.

The central message of the study by Domeier et al. (5a) is that $\mathrm{Ins}_{3} \mathrm{R}$ activation underlies the positive inotropic action of endothelin-1 (ET-1) on ventricular myocytes. ET-1 is a potent vasoconstrictor hormone that has been shown to have inotropic, arrhythmic, and hypertrophic effects on cardiomyocytes. Domeier et al. present molecular evidence for $\mathrm{InsP}_{3} \mathrm{R}$ expression in their rabbit ventricular myocytes and demonstrate that ET-1 provokes increases in cellular Ins $\mathrm{P}_{3}$ concentration. Given these two pieces of evidence, it is inevitable that $\operatorname{InsP}_{3} \mathrm{R}$ evoked $\mathrm{Ca}^{2+}$ signals will occur. However, the critical question is, in what way can the relatively few $\mathrm{InsP}_{3} \mathrm{Rs}$ influence cardiac $\mathrm{Ca}^{2+}$ signaling?

The most obvious effect of $\mathrm{InsP}_{3} \mathrm{Rs}$ would be to contribute to systolic $\mathrm{Ca}^{2+}$ increases. Because of their ability to act as CICR channels, InsP $\mathrm{P}_{3} \mathrm{Rs}$ could tune into to the regular activation of VOCs and boost the systolic $\mathrm{Ca}^{2+}$ signal. In agreement with this notion, Domeier et al. found that application of ET-1 to electrically paced rabbit ventricular myocytes caused a significant increase in the amplitude of systolic $\mathrm{Ca}^{2+}$ transients. Using a pharmacological inhibitor of $\operatorname{InsP}_{3} \mathrm{R}$ activation and adenovirus-mediated infection of cells with an " $\mathrm{InsP}_{3}$ affinity trap" (essentially a high-affinity mutant of the $\operatorname{Ins}_{3} \mathrm{R}$ ligand binding domain), they demonstrated that the $\operatorname{InsP}_{3} \mathrm{R}$ activity was responsible for all of the ET-1-stimulated increase in systolic $\mathrm{Ca}^{2+}$ signals. Given that receptors for ET-1 can couple to several $\mathrm{G}$ proteins (e.g., $\mathrm{G}_{\mathrm{q} / 11}, \mathrm{G}_{12 / 13}, \mathrm{G}_{\mathrm{i}}$ ) that can putatively activate a host of downstream processes, it is perhaps a little surprising that all of the inotropic effect of ET- 1 is due to $\mathrm{InsP}_{3}$. However, the data of Domeier et al. pinpoint the significance of $\mathrm{InsP}_{3} \mathrm{Rs}$ in the context of hormonal stimulation of the heart.

Despite this convincing demonstration for a role of $\mathrm{InsP}_{3} \mathrm{Rs}$ in modulating cardiac $\mathrm{Ca}^{2+}$ signaling, there are still more questions than answers with regard to the role of these channels in the heart. For example, there are unexplained differences in the effect of $\mathrm{InsP}_{3} \mathrm{R}$ activation in the ventricular myocytes from different mammalian species. In the case of rat ventricular cardiomyocytes, the predominant effect of $\mathrm{InsP}_{3} \mathrm{R}$ activation appears to be the generation of proarrhythmic $\mathrm{Ca}^{2+}$ transients, with only a modest inotropic effect (16), whereas in the study by Domeier et al. (5a) using rabbit ventricular myocytes Ins $\mathrm{P}_{3} \mathrm{R}$ activation caused inotropy but not arrhythmias. In contrast, with cat ventricular myocytes $\mathrm{InsP}_{3} \mathrm{R}$ activation does not generate inotropy or arrhythmias. Domeier et al. comment on these interesting species differences and suggest that the functional effect of $\mathrm{Ins}_{3} \mathrm{Rs}$ may depend on the degree to which $\mathrm{SR} \mathrm{Ca}^{2+}$ release contributes to systolic $\mathrm{Ca}^{2+}$ transients. They argue that species in which $\mathrm{SR} \mathrm{Ca}^{2+}$ release is a major component of the systolic $\mathrm{Ca}^{2+}$ signal during $\mathrm{EC}$ coupling (substantial in rat and less so in cat) will be most profoundly affected by the participation of $\mathrm{InsP}_{3} \mathrm{Rs}$. 


\section{H580}

Although the effects of $\mathrm{InsP}_{3} \mathrm{Rs}$ may be variable in mammalian ventricular myocytes, there is much more consistency in the response of atrial cells across species. For example, substantial InsP-mediated responses have been demonstrated in atrial myocytes from mouse (9), rat (4), and cat (25). For an unknown reason, atrial myocytes express more $\mathrm{InsP}_{3} \mathrm{Rs}$ than their ventricular counterparts (10). This probably explains why $\mathrm{InsP}_{3} \mathrm{R}$-evoked changes in $\mathrm{Ca}^{2+}$ signaling are much easier to observe in atrial cells. This is also true for neonatal myocytes (12) and Purkinje cells (19), which similarly have substantial $\mathrm{InsP}_{3} \mathrm{R}$ expression. In fact, it is an interesting correlation that cardiac cells without t-tubules (i.e., not ventricular myocytes) appear to express the most InsP ${ }_{3}$ Rs. Given that nontubulated cells rely on the centripetal propagation of $\mathrm{Ca}^{2+}$ waves for $\mathrm{EC}$ coupling (5), InsP $\mathrm{P}_{3} \mathrm{Rs}$ could play a critical role alongside the RyRs in boosting systolic $\mathrm{Ca}^{2+}$ transients.

In general, stimulation of cardiac myocytes with an $\mathrm{InsP}_{3^{-}}$ generating agonist, such as ET-1, provokes inotropy and arrhythmias. However, with both adult atrial and ventricular myocytes the degree of inotropy caused by $\operatorname{InsP}_{3} \mathrm{R}$ activation is generally modest compared with their substantial proarrhythmic effect. Indeed, the activation of $\mathrm{InsP}_{3} \mathrm{Rs}$ in cardiac tissue has been more commonly linked to the generation of arrhythmias than any other cellular effect. This begs the question of whether the $\mathrm{InsP}_{3} \mathrm{Rs}$ are more likely to have a pathological role in the adult heart. However, it would seem strange that the heart would express $\mathrm{Ca}^{2+}$ channels that allow modest positive changes in EC coupling while generating substantial arrhythmic activity. Perhaps Ins $\mathrm{P}_{3}$ Rs have other, more significant, cardiac functions that are distinct from modulating EC coupling?

One such putative role of cardiac InsP $\mathrm{P}_{3} \mathrm{Rs}$ could be to generate $\mathrm{Ca}^{2+}$ signals that are completely dissociated from EC coupling. Indeed, it appears that $\mathrm{Ins}_{3} \mathrm{Rs}$ are strategically located within cardiomyocytes for this purpose. Several studies have pinpointed the location of $\mathrm{InsP}_{3} \mathrm{Rs}$ within or around the nucleus $(1,12,21)$. Furthermore, it is apparent that direct activation of $\mathrm{InsP}_{3} \mathrm{Rs}$ in permeabilized myocytes, or stimulation of intact cells with $\mathrm{InsP}_{3}$-generating stimuli, can give rise to nucleus-specific $\mathrm{Ca}^{2+}$ signals, and that the nuclear envelope is an $\mathrm{InsP}_{3}$-releasable $\mathrm{Ca}^{2+}$ store $(4,8,12,21,24)$. Relative to the cytosolic compartment (which has abundant $\mathrm{Ca}^{2+}$-ATPases and mitochondria), nucleoplasm has a poor $\mathrm{Ca}^{2+}$ sequestration capacity. This means that $\mathrm{Ca}^{2+}$ signals typically persist longer within nuclei. Indeed, a transient perinuclear $\mathrm{Ca}^{2+}$ release event is likely to barely impact on the cytosol because of sequestration, whereas it can penetrate into the nucleus and persist much longer (11). It has been shown that opening of peri- or intranuclear InsP $\mathrm{P}_{3} \mathrm{Rs}$ is sufficient to activate $\mathrm{Ca}^{2+}$ sensitive gene reporters in myocytes (21), indicating that $\mathrm{InsP}_{3}$-dependent nucleus-specific $\mathrm{Ca}^{2+}$ signals are capable of driving cardiac gene transcription. The autonomous activation of nuclear $\mathrm{InsP}_{3} \mathrm{Rs}$ may provide a mechanism for dissociating the $\mathrm{Ca}^{2+}$ signals underlying gene transcription from the bulk $\mathrm{Ca}^{2+}$ changes that occur during EC coupling (15).

A further function for $\mathrm{InsP}_{3} \mathrm{Rs}$, for which there have also been several recent reports, is to generate $\mathrm{Ca}^{2+}$ signals in the developing heart $(7,13,18)$. Because of their ability to act as autonomous CICR channels, InsP ${ }_{3} \mathrm{Rs}$ can generate repetitive $\mathrm{Ca}^{2+}$ oscillations. This is well described for nonexcitable cell types, which largely rely on $\mathrm{InsP}_{3} \mathrm{Rs}$ for $\mathrm{Ca}^{2+}$ mobilization (2).
Similar periodic $\operatorname{InsP}_{3} \mathrm{R}$ activity appears to underlie the initiation of pacemaking and differentiation of embryonic cardiac myocytes. The dependence of cardiac myocytes on $\mathrm{InsP}_{3} \mathrm{Rs}$ evidently changes with development. They are very obviously present in embryonic myocytes, and are still abundant in neonates even though EC coupling has switched to VOCs/ RyRs (12), but their expression rapidly diminishes in the postnatal period. This developmental loss of $\mathrm{InsP}_{3} \mathrm{R}$ expression is reversed under some pathological conditions, such as heart failure (6), mitral valve disease (22), and atrial fibrillation (23).

It is now beyond doubt that cardiac myocytes express functional $\mathrm{InsP}_{3} \mathrm{Rs}$, and that these channels are present from embryo to adult. However, their cellular roles are still rather enigmatic. They have been linked to inotropy, chronotropy, arrhythmias, pacemaking, and gene transcription. That a relatively small population of $\mathrm{Ca}^{2+}$ release channels can impact on so many different processes is very intriguing given that myocytes see regular subsecond $\mathrm{Ca}^{2+}$ signals via EC coupling. Either the modulation of EC coupling by $\mathrm{InsP}_{3} \mathrm{Rs}$ or the strategic location of $\mathrm{InsP}_{3} \mathrm{Rs}$ allows them to have a disproportionately large effect.

\section{REFERENCES}

1. Bare DJ, Kettlun CS, Liang M, Bers DM, Mignery GA. Cardiac type 2 inositol 1,4,5-trisphosphate receptor: interaction and modulation by calcium/ calmodulin-dependent protein kinase II. J Biol Chem 280: 15912-15920, 2005.

2. Berridge MJ. Calcium oscillations. J Biol Chem 265: 9583-9586, 1990.

3. Bers DM. Cardiac excitation-contraction coupling. Nature 415: 198-205, 2002.

4. Bootman MD, Harzheim D, Smyrnias I, Conway SJ, Roderick HL. Temporal changes in atrial EC-coupling during prolonged stimulation with endothelin-1. Cell Calcium 42: 489-501, 2007.

5. Bootman MD, Higazi DR, Coombes S, Roderick HL. Calcium signalling during excitation-contraction coupling in mammalian atrial myocytes. J Cell Sci 119: 3915-3925, 2006.

5a.Domeier TL, Zima AV, Maxwell JT, Huke S, Mignery GA, Blatter LA. $\mathrm{IP}_{3}$ receptor-dependent $\mathrm{Ca}^{2+}$ release modulates excitation-contraction coupling in rabbit ventricular myocytes. Am J Physiol Heart Circ Physiol (November 30, 2007). doi:10.1152/ajpheart.01155.2007.

6. Go LO, Moschella MC, Watras J, Handa KK, Fyfe BS, Marks AR. Differential regulation of two types of intracellular calcium release channels during end-stage heart failure. J Clin Invest 95: 888-894, 1995.

7. Kapur N, Banach K. Inositol-1,4,5-trisphosphate-mediated spontaneous activity in mouse embryonic stem cell-derived cardiomyocytes. J Physiol 581: 1113-1127, 2007.

8. Kockskämper J, Seidlmayer L, Walther S, Hellenkamp K, Maier LS, Pieske B. Endothelin-1 enhances nuclear $\left[\mathrm{Ca}^{2+}\right]$ transients in atrial myocytes via inositol 1,4,5-trisphosphate-dependent $\mathrm{Ca}^{2+}$ release from perinuclear $\mathrm{Ca}^{2+}$ stores. J Cell Sci. In press.

9. Li X, Zima AV, Sheikh F, Blatter LA, Chen J. Endothelin-1-induced arrhythmogenic $\mathrm{Ca}^{2+}$ signaling is abolished in atrial myocytes of inositol1,4,5-trisphosphate $\left(\mathrm{IP}_{3}\right)$-receptor type 2-deficient mice. Circ Res 96: 1274-1281, 2005.

10. Lipp P, Laine M, Tovey SC, Burrell KM, Berridge MJ, Li W, Bootman MD. Functional $\mathrm{Ins}_{3}$ receptors that may modulate excitationcontraction coupling in the heart. Curr Biol 10: 939-942, 2000.

11. Lipp P, Thomas D, Berridge MJ, Bootman MD. Nuclear calcium signalling by individual cytoplasmic calcium puffs. EMBO J 16: 7166-7173, 1997.

12. Luo D, Yang D, Lan X, Li K, Li X, Chen J, Zhang Y, Xiao RP, Han Q, Cheng H. Nuclear $\mathrm{Ca}^{2+}$ sparks and waves mediated by inositol 1,4,5-trisphosphate receptors in neonatal rat cardiomyocytes. Cell Calcium (June 19, 2007) doi: j.ceca.2007.04.017.

13. Mery A, Aimond F, Menard C, Mikoshiba K, Michalak M, Puceat M. Initiation of embryonic cardiac pacemaker activity by inositol 1,4,5-trisphosphate-dependent calcium signaling. Mol Biol Cell 16: 2414-2423, 2005.

14. Miyakawa T, Maeda A, Yamazawa T, Hirose K, Kurosaki T, Iino M. Encoding of $\mathrm{Ca}^{2+}$ signals by differential expression of $\mathrm{IP}_{3}$ receptor subtypes. EMBO J 18: 1303-1308, 1999. 
15. Molkentin JD. Dichotomy of $\mathrm{Ca}^{2+}$ in the heart: contraction versus intracellular signaling. J Clin Invest 116: 623-626, 2006.

16. Proven A, Roderick HL, Conway SJ, Berridge MJ, Horton JK, Capper SJ, Bootman MD. Inositol 1,4,5-trisphosphate supports the arrhythmogenic action of endothelin-1 on ventricular cardiac myocytes. J Cell Sci 119: 3363-3375, 2006.

17. Roderick HL, Berridge MJ, Bootman MD. Calcium-induced calcium release. Curr Biol 13: R425, 2003.

18. Sasse P, Zhang J, Cleemann L, Morad M, Hescheler J, Fleischmann BK. Intracellular $\mathrm{Ca}^{2+}$ oscillations, a potential pacemaking mechanism in early embryonic heart cells. J Gen Physiol 130: 133-144, 2007.

19. Stuyvers BD, Dun W, Matkovich S, Sorrentino V, Boyden PA, ter Keurs HE. $\mathrm{Ca}^{2+}$ sparks and waves in canine Purkinje cells: a triple layered system of $\mathrm{Ca}^{2+}$ activation. Circ Res 97: 35-43, 2005.

20. Woodcock EA, Matkovich SJ, Binah $\mathbf{O}$. $\operatorname{Ins}(1,4,5) \mathrm{P}_{3}$ and cardiac dysfunction. Cardiovasc Res 40: 251-256, 1998.
21. Wu X, Zhang T, Bossuyt J, Li X, McKinsey TA, Dedman JR, Olson EN, Chen J, Brown JH, Bers DM. Local InsP ${ }_{3}$-dependent perinuclear $\mathrm{Ca}^{2+}$ signaling in cardiac myocyte excitation-transcription coupling. $J$ Clin Invest 116: 675-682, 2006.

22. Yamada J, Ohkusa T, Nao T, Ueyama T, Yano M, Kobayashi S, Hamano K, Esato K, Matsuzaki M. Up-regulation of inositol 1,4,5 trisphosphate receptor expression in atrial tissue in patients with chronic atrial fibrillation. J Am Coll Cardiol 37: 1111-1119, 2001.

23. Zhao ZH, Zhang HC, Xu Y, Zhang P, Li XB, Liu YS, Guo JH. Inositol-1,4,5-trisphosphate and ryanodine-dependent $\mathrm{Ca}^{2+}$ signaling in a chronic dog model of atrial fibrillation. Cardiology 107: 269-276, 2007.

24. Zima AV, Bare DJ, Mignery GA, Blatter LA. IP ${ }_{3}$-dependent nuclear $\mathrm{Ca}^{2+}$ signalling in the mammalian heart. $J$ Physiol 584: 601-611, 2007.

25. Zima AV, Blatter LA. Inositol-1,4,5-trisphosphate-dependent $\mathrm{Ca}^{2+}$ signalling in cat atrial excitation-contraction coupling and arrhythmias. J Physiol 555: 607-615, 2004.

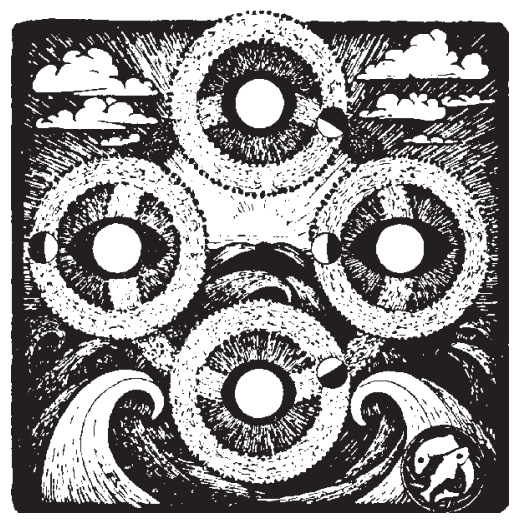

